\title{
Aflatoxin M1 determination in raw milk using a flow-injection immunoassay system
}

\author{
Mihaela Badea ${ }^{\mathrm{a}, \mathrm{d}, *}$, Laura Micheli ${ }^{\mathrm{a}}$, Maria Cristina Messia ${ }^{\mathrm{b}}$, Tiziana Candigliota ${ }^{\mathrm{b}}$, \\ Emanuele Marconi ${ }^{\mathrm{b}}$, Toby Mottram ${ }^{\mathrm{c}}$, Maria Velasco-Garcia ${ }^{\mathrm{c}}$, \\ Danila Moscone $^{\mathrm{a}}$, Giuseppe Palleschi ${ }^{\mathrm{a}}$ \\ a Dipartimento di Scienze e Tecnologie Chimiche, Università di Roma "Tor Vergata", via della Ricerca Scientifica, 00133 Rome, Italy \\ ${ }^{\mathrm{b}}$ DISTAAM, Università del Molise, Via De Sanctis, 86100 Campobasso, Italy \\ ' Silsoe Research Institute, Wrest Park, Silsoe, Bedford MK45 4HS, UK \\ ${ }^{\mathrm{d}}$ Research Center for Automated Methods of Analysis, Faculty of Chemistry, University of Bucharest, Sos. Panduri, 90-92, Bucharest, Romania
}

Received 11 December 2003; received in revised form 11 May 2004; accepted 17 May 2004

Available online 23 July 2004

\begin{abstract}
A flow-injection immunoassay (FI-IA) method with amperometric detection for aflatoxin M1 (AFM1) determination in milk has been developed. The first step consists in an incubation of the sample containing AFM1 (Ag) with fixed amounts of anti-AFM1 antibody (Ab) and of the tracer ( $\mathrm{Ag}^{*}$, AFM1 covalently coupled to HRP) until equilibrium is reached. In this mixture a competition occurs between Ag and $\mathrm{Ag}^{*}$ for the $\mathrm{Ab}$. The mixture is then injected into a flow system where the separation of the free tracer $\left(\mathrm{Ag}^{*}\right)$ and the antibody-bound tracer $\left(\mathrm{AbAg}^{*}\right)$ is performed in a column with immobilized Protein $\mathrm{G}$. The antigen-antibody complexes are retained in the column due to the high affinity of the Protein $G$ for the antibody. The activity of the eluted enzyme label is then amperometrically detected.

The immunoassay was optimised relative to conditions for antibody-antigen incubation ( $\mathrm{pH}$, incubation time, ionic strength, temperature) and enzymatic label detection. This method showed a dynamic concentration range between 20 and 500 ppt AFM1, a low detection limit $(11 \mathrm{ppt})$, good reproducibility (RSD $<8 \%$ ) and a high throughput (six samples per hour in triplicate). Different milk samples were analysed and the results were in good agreement with those obtained by HPLC using the AOAC 2000.08 method.
\end{abstract}

(C) 2004 Elsevier B.V. All rights reserved.

Keywords: Aflatoxin M1; Flow-injection immunoassay; Protein G; Amperometric detection; Raw milk

\section{Introduction}

Aflatoxins are highly toxic mycotoxins produced by Aspergillus species growing in a wide range of food and animal feedstuffs [1]. When aflatoxin B1 (AFB1), the most toxic aflatoxin, is ingested by cows, it is transformed into its hydroxylated product, aflatoxin M1 (AFM1), which is then secreted in the milk [2]. Although its toxicity is lower than that of its parent compound, AFM1 is known for its hepatotoxic and carcinogenic effect [3]. Unfortunately, AFM1 is relatively stable during milk pasteurisation and storage as well as during the preparation of various dairy products [4].

\footnotetext{
* Corresponding author. Fax: +3906 72594328.

E-mail address: mihaela.badea@uniroma2.it (M. Badea).
}

To date, aflatoxins are regulated in many countries world-wide [5]. The current maximum level set by the European Union is $0.05 \mu \mathrm{g} / \mathrm{kg}$ for Aflatoxin M1 in milk [6]. To minimize the occurrence of AFM1, it is essential to trace the sources of contamination using rapid, selective, sensitive and cost effective assays.

Several procedures for aflatoxin M1 determination have been developed. Methods based on thin-layer chromatography (TLC), high-performance liquid chromatography (HPLC) or enzyme-linked immunosorbent assay (ELISA) are commonly used in routine analysis [7]. TLC was the first method used for aflatoxin M1 determination, but in the last decade has been almost completely replaced by HPLC and fluorimetric techniques [8-11]. These techniques require extensive preparation steps and well-trained personnel [12]. Moreover, the reagents and instrumentation used are expensive. 
In the last decade the production of specific antibodies for aflatoxins has allowed the development of ELISA methods based on direct or indirect competition [12-14]. Currently, some colorimetric ELISA kits for AFM1 determination in milk and dairy products are commercially available [15]. The ELISA methods, however, present some drawbacks such as long incubation time, washing and mixing steps.

Responding to the need for more suitable methods, some rapid methods based on the use of biosensors or immunosensors have been proposed in the last years. An immunoaffinity fluorimetric biosensor was assembled in an automated system that can measure up to $50 \mathrm{ppb}$ Aflatoxin M1 [16], but its detection limit $(0.1 \mathrm{ppb})$ is too high for it to be useful for aflatoxin M1 determination in milk.

Sibanda et al. [17] have developed a membrane-based flow-through enzyme immunoassay. A detection limit of $50 \mathrm{ppt}$ was achieved using a preconcentration step based on an immunoaffinity column, the total assay time being $30 \mathrm{~min}$.

A bilayer lipid membrane (BLM)-based biosensor and related thin-film technology were investigated for AFM1 monitoring of milk using a flow-injection system [18]. This very fast method (four samples per minute) permits a continuous monitoring of milk with a detection limit around 200 ppt.

The aim of our work was to develop a method for AFM1 determination that can combine the rapidity and reproducibility of the flow-injection technique with the high selectivity and sensitivity characteristics of immunochemical reactions. We adapted a generic flow-injection immunoassay (FI-IA) system initially developed for atrazine as a model compound [19]. This was then adapted and applied with very good results for triazine herbicides [20] and alkyl phenol ethoxylate surfactants determination in waste water [21].

The generic system is based on an off-line incubation of the antigen $\left(\mathrm{Ag}\right.$, analyte), the tracer $\left(\mathrm{Ag}^{*}\right.$, enzyme-labelled antigen) and the antibody ( $\mathrm{Ab}$ ) until equilibrium is reached. Then this mixture is introduced into a flow-injection system where the antigen-antibody complexes ( $\mathrm{AgAb}$ and $\mathrm{Ag}^{*} \mathrm{Ab}$ ) are trapped on the Protein $G$ column, while the free, i.e. unbound, tracer is eluted and detected by measuring the activity of the enzyme label. The reason for using the Protein $\mathrm{G}$ column is due to its high affinity for the constant region (Fc region) of immunoglobulins.

Most immunoassays based on the Protein G column separation monitor the fraction of the tracer bound inside the Protein $\mathrm{G}$ column as $\mathrm{Ag}^{*} \mathrm{Ab}$ complex. This choice involves a more complicated scheme since there are four steps: incubation of the reagents, antigen-antibody complex trapping inside the Protein G column, monitoring of the enzyme label by substrate injection and regeneration of the Protein $G$ column by desorption of the antigen-antibody complexes. By contrast, when the free fraction of the tracer $\left(\mathrm{Ag}^{*}\right)$ is monitored, a higher sample throughput is obtained and the Protein $\mathrm{G}$ column does not need to be regenerated between assays. The regeneration of the Protein G column can be performed after $50-100$ assays and is dependent upon the amount of the Ab used.
For AFM1 determination we developed a FI-IA system based on the amperometric detection of horseradish peroxidase (HRP), which serves as the enzymatic label for tracer $\mathrm{Ag}$ in the eluate.

\section{Experimental}

\subsection{Reagents, method and instrumentation for FI-IA}

\subsubsection{Reagents}

Rat monoclonal anti-aflatoxin antibody (MAB586P) was purchased from Maine Biotechnology Services (Portland, ME, USA). Stock solutions (100 ppm) of aflatoxin M1 (AFM1), aflatoxin B1 (AFB1), aflatoxin B2 (AFB2), aflatoxin G1 (AFG1) and ochratoxin, obtained from Alexis Biochemicals (Carlsbad, CA, USA) were prepared in methanol (Carlo Erba, Milan, Italy). Protein G immobilized on highly cross-linked $(4 \%)$ beaded agarose fast flow medium with a binding capacity of $37 \mathrm{mg} \mathrm{IgG} \mathrm{m}^{-1}$ gel was purchased from Sigma (St. Louis, MO, USA).

An AFM1-HRP conjugate from the Ridascreen ${ }^{\circledR}$ Aflatoxin M1 ELISA kit (R-Biopharm, Darmstadt, Germany) was used. Horseradish peroxidase Type VI-A with an activity of $1310 \mathrm{U} \mathrm{mg}^{-1}, 3,3^{\prime}, 5,5^{\prime}$-tetramethylbenzidine (TMB), hydrogen peroxide $30 \%(\mathrm{w} / \mathrm{v})$, citric acid (anhydrous), Tween 20 and sodium chloride were from Sigma. $\mathrm{Na}_{2} \mathrm{HPO}_{4}$ and $\mathrm{NaH}_{2} \mathrm{PO}_{4} \cdot \mathrm{H}_{2} \mathrm{O}$ were from Carlo Erba. The T-connector valves and PTFE connection tubes (i.d. $0.5 \mathrm{~mm}$ ) were purchased from Supelco (Bellefonte, PA, USA).

Water produced in a Milli-Q system (Millipore, Beford, MA, USA) was used for preparing all the solutions.

\subsubsection{Methods and instrumentation}

All affinity reactions were performed off-line by mixing the sample with the tracer (AFM1-HRP) and antibody until equilibrium was reached. The mixture was then introduced via a $20 \mu \mathrm{l}$ injection loop into the flow system using a six-way Rheodyne injection valve, model 7125 (Cotati, CA). A borosilicate glass chromatography column $(25 \mathrm{~mm}$ length and $0.35 \mathrm{ml}$ bed volume) equipped with frits (PTFE, pore size $100 \mu \mathrm{m}$ ) from Omnifit (Rockville Centre, NY, USA) was filled with Protein G agarose beads and inserted in the carrier flow channel after the injection valve (Fig. 1). A four channel peristaltic pump, Minipuls 3 (Gilson, France) was used for pumping the following solutions: the carrier of $50 \mathrm{mmoll}^{-1}$ phosphate buffer, also containing $100 \mathrm{mmol}^{-1} \mathrm{NaCl}, 10 \mathrm{mmol}^{-1} \mathrm{MgCl}_{2}$ and $0.03 \%(\mathrm{v} / \mathrm{v})$ Tween 20 (channel 1); substrate solutions of $0.5 \mathrm{mmol}^{-1}$ TMB prepared in water (channel 2) and $10 \mathrm{mmoll}^{-1} \mathrm{H}_{2} \mathrm{O}_{2}$ prepared in $100 \mathrm{mmoll}^{-1}$ phosphate-citrate buffer, also containing $100 \mathrm{mmoll}^{-1} \mathrm{NaCl}$ and 0.03 concentration.

\subsubsection{Milk sample analysis}

Raw and UHT (Ultra high temperature) sterilized milk samples, either spiked or naturally contaminated with 


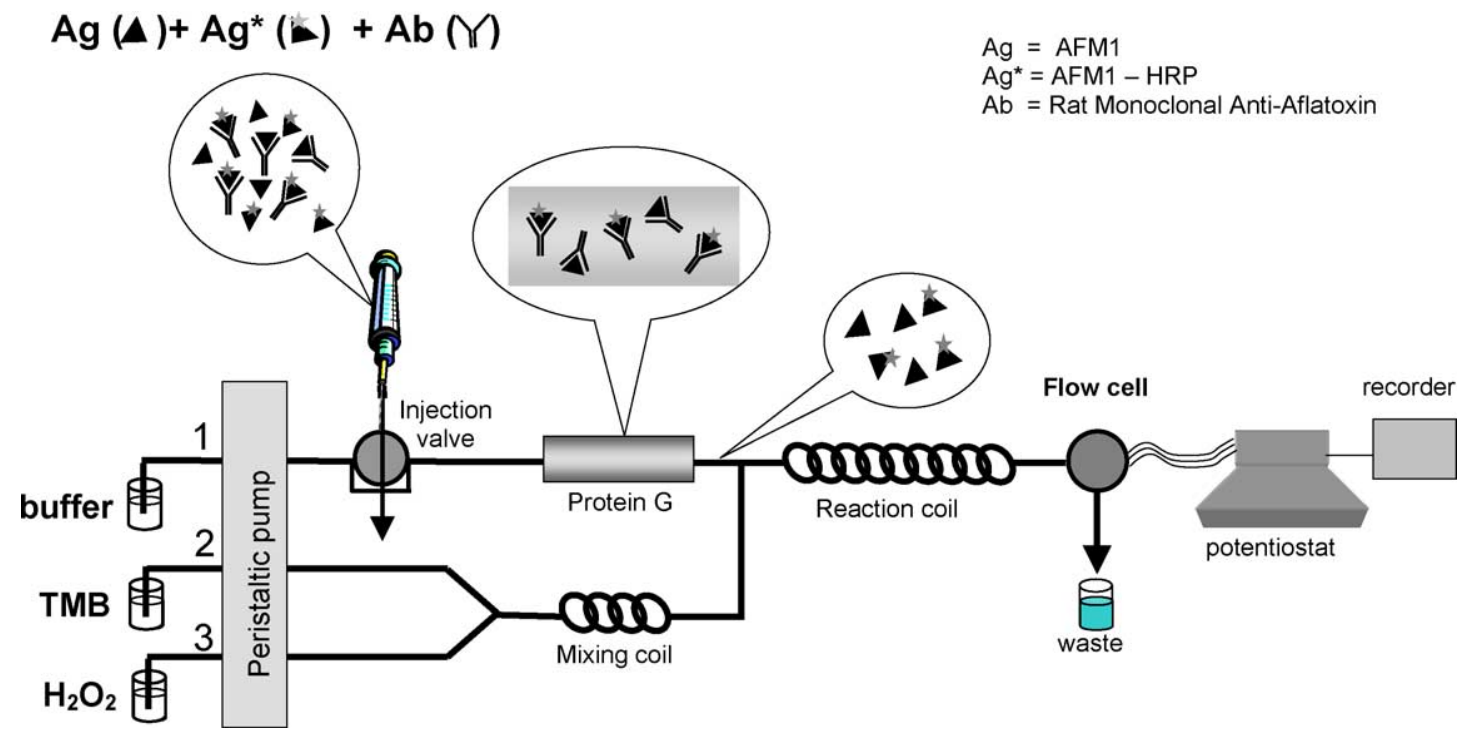

Fig. 1. Flow-injection immunoassay set-up.

AFM1, were provided by Parmalat (Parma, Italy). The fat content in these samples was around $3.5 \%$.

When raw milk samples were analysed, they were first treated by heating for $2 \mathrm{~min}$ at $90^{\circ} \mathrm{C}$ to inactivate endogenous lactoperoxidase (for UHT milk samples this step was not necessary). Samples were then diluted 1:1 with $100 \mathrm{mM}$ phosphate buffer, $\mathrm{pH}$ 6.5, which also contained $200 \mathrm{mM}$ $\mathrm{NaCl}$ and $20 \mathrm{mM} \mathrm{MgCl}_{2}$, and incubated 60 min off-line with $\left(A g_{w}^{*}\right)$ and $\left(\mathrm{Ab}_{\mathrm{w}}\right)$ before injection into the FI-IA system.

\subsection{Reagents, methods and instrumentation for HPLC method}

\subsubsection{Reagents and instrumentation}

Aflatoxin M1 from Aspergillus flavus were purchased from Sigma and Afla M1 Aflatoxin testing kits (25 columns) were from Vicam (Safe Food, BO, Italy).

The reversed phase HPLC analytical system employed a Nova-Pak $\mathrm{C}_{18}$ column $(60 \AA$, $4 \mu \mathrm{m}, 3.9 \times 300 \mathrm{~mm})$ from Waters (Milford, MA, USA) and a Rheodyne injection valve with a $50 \mu$ injection loop. The mobile phase was a mixture water- $\mathrm{CH}_{3} \mathrm{CN}-\mathrm{CH}_{3} \mathrm{OH}$ (65:25:10) and the flow rate was $0.8 \mathrm{ml} \mathrm{min}^{-1}$. Fluorimetric detection was used with $365 \mathrm{~nm}$ excitation and $435 \mathrm{~nm}$ emission.

\subsubsection{Methods for sample preparation}

The milk was warmed to $35-37^{\circ} \mathrm{C}$ and centrifuged at $3000 \mathrm{~g}$ to remove the fat. Fifty mililitre of de-fatted milk was then pipetted into the syringe barrel and allowed to pass through the immunoaffinity column at a rate of 2-3 ml min ${ }^{-1}$. The column was washed with $20 \mathrm{ml}$ water at constant flow rate. Finally, Aflatoxin M1 was slowly eluted from the column with $4 \mathrm{ml}$ of acetonitrile and the eluate was collected in a conical tube and evaporated to dryness using a gentle stream of $\mathrm{N}_{2}$. The dried product was diluted with
$200 \mu 1$ of mobile phase and was injected into the HPLC system.

\section{Results and discussion}

\subsection{Electrochemical detection of enzyme label}

The flow-injection immunoassay method proposed here is based on an AFM1 conjugate with horseradish peroxidase (AFM1-HRP) as tracer. HRP catalyses the oxidation reaction of various hydrogen-donating substrates with hydrogen peroxide to produce oxidized substrate and water. One of the most commonly used substrates for the spectrophotometric determination HRP activity is TMB. The successful use of TMB as electrochemical substrate for an HRP-based enzyme immunoassay had already been demonstrated in our lab [22]. In that study, the electrochemical behaviour of both TMB and $\mathrm{TMB}_{\mathrm{Ox}}$ were investigated in order to optimise the conditions for amperometrically determining HRP activity using a flow-injection analysis at a glassy carbon electrode.

A cyclic voltammetric investigation of TMB was carried out using a glassy carbon electrode. The reported results supported the mechanism previously proposed, in which there is formation of a radical cation, and then two subsequent one electron step processes for the oxidation of TMB by $\mathrm{HRP}$ in the presence of $\mathrm{H}_{2} \mathrm{O}_{2}$. The most interesting result, in terms of the application considered here, was the generation of an electrocatalytic current (the difference between the cathodic waves in buffer with or without the presence of HRP). Thus, the addition of HRP to a solution containing the two substrates (TMB and $\mathrm{H}_{2} \mathrm{O}_{2}$ ) led to the consumption of TMB and consequently to a decrease in the oxidation and an increase in the reduction currents respectively. 
Further studies then allowed the choice of a working potential of $+100 \mathrm{mV}$ versus $\mathrm{Ag} / \mathrm{AgCl}$ for the measurement of HRP activity, and these have been adopted for use here. At this potential the current background was near zero and no substrate oxidation occurred. These conditions are the optimum for enzymatic activity determination when a small amount of product $\left(\mathrm{TMB}_{\mathrm{ox}}\right)$ needs to be measured in the presence of high concentrations of substrate.

Having established the electrochemical system to use, optimisation of the buffer conditions and substrate concentrations for HRP detection was performed for the FIA system shown in Fig. 1, but without the Protein G column inserted. Instead, labelling enzyme (HRP) was injected directly, and a $0.05 \mathrm{U} \mathrm{ml}^{-1} \mathrm{HRP}$ solution was chosen for these studies.

The $\mathrm{pH}$ of the carrier and substrate solutions were optimised in a first step (results not shown). Since the optimum $\mathrm{pH}$ for HRP activity is 8 while that for detection of $\mathrm{TMB}_{\mathrm{ox}}$ is around 5, a compromise was found so that the $\mathrm{pH}$ of the carrier solution was as high as possible while the mixture that resulted in the flow cell would be close to the optimal value for electrochemical detection. Regarding the TMB solution, due to its solubility problems in phosphate-citrate buffer, it was decided to prepare that substrate in distilled water.

Following trials with various buffers and $\mathrm{pHs}$, the best results for HRP activity determination using this flow-injection system were determined to be the following: a carrier solution of $50 \mathrm{mM}$ phosphate buffer, $\mathrm{pH} 6.5$, containing $100 \mathrm{mM}$ $\mathrm{NaCl}$ and $10 \mathrm{mM} \mathrm{MgCl}$ (which is included as an activator of HRP). For the $\mathrm{H}_{2} \mathrm{O}_{2}$ solution, the highest signals were obtained for a $100 \mathrm{mM}$ phosphate-citrate buffer, $\mathrm{pH} 5.0$, with $100 \mathrm{mM} \mathrm{NaCl}$.

The optimum concentrations of TMB and $\mathrm{H}_{2} \mathrm{O}_{2}$ to employ for the measurement of HRP activity were then studied

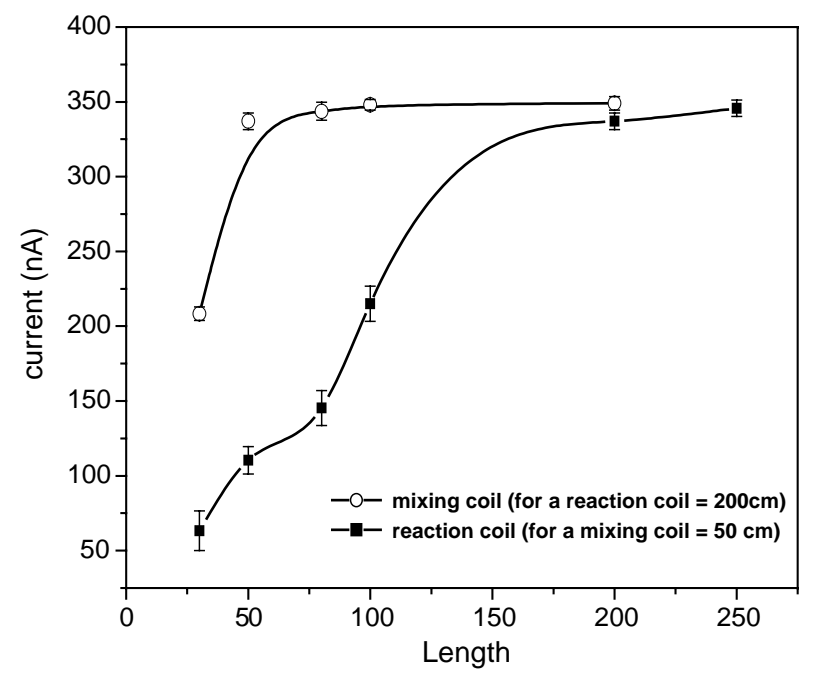

Fig. 3. Influence of the mixing and reaction coil length on HRP activity determination. Working conditions: $0.05 \mathrm{U} \mathrm{ml}^{-1} \mathrm{HRP} ; 10 \mathrm{mM} \mathrm{H}_{2} \mathrm{O}_{2}$; $0.5 \mathrm{mM} \mathrm{TMB}$; total flow rate $0.9 \mathrm{ml} \mathrm{min}^{-1}$ (the flow rate for each channel was $0.3 \mathrm{ml} \mathrm{min}^{-1}$ ).

using the enzyme concentration reported above. The results, reported in Fig. 2A and $\mathrm{B}$ indicated that the highest current outputs were achieved for $0.5 \mathrm{mM}$ TMB and $10 \mathrm{mM} \mathrm{H}_{2} \mathrm{O}_{2}$, respectively. Higher $\mathrm{H}_{2} \mathrm{O}_{2}$ concentrations could not be used since above $10 \mathrm{mM}$ the signals became irreproducible and passivation of the electrode was observed.

The influence of the length of both mixing and reaction coils was also studied (Fig. 3). Regarding the mixing coil (for the two enzymatic substrates, see Fig. 1), FIA output currents plateaued at $50 \mathrm{~cm}$ of length. Using this value, the optimum length for the reaction coil, where the enzymatic reaction takes place, was explored and a much longer tube was found to be necessary. On the basis of these experiments
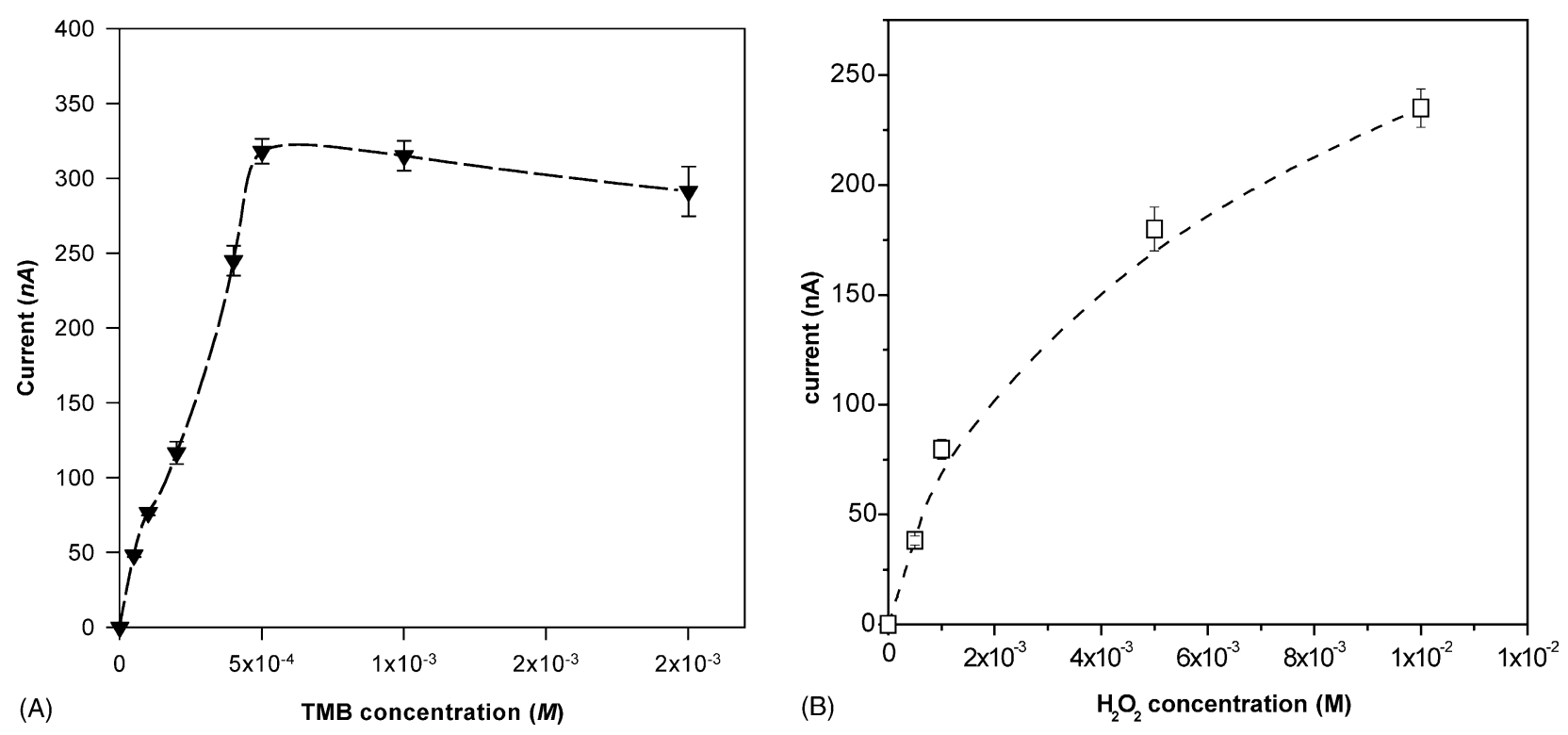

Fig. 2. Influence of the TMB (A) and $\mathrm{H}_{2} \mathrm{O}_{2}$ (B) concentration on the determination of HRP activity. Working conditions: (A) $0.05 \mathrm{U} \mathrm{ml} \mathrm{l}^{-1} \mathrm{HRP}$; $10 \mathrm{mM}^{\circ}$ $\mathrm{H}_{2} \mathrm{O}_{2}$ (B) $0.05 \mathrm{U} \mathrm{ml}^{-1} \mathrm{HRP} ; 0.5 \mathrm{mM}$ TMB. 
a $50 \mathrm{~cm}$ mixing coil and a $200 \mathrm{~cm}$ reaction coil were chosen for further work.

Using these optimised conditions for the electrochemical determinination of HRP activity, a calibration curve was obtained and showed good linearity up to $100 \mathrm{mU} \mathrm{ml}^{-1}$ HRP with a LOD of $0.25 \mathrm{mU} \mathrm{ml}^{-1}$. The good reproducibility $(\mathrm{RSD}=2.34 \%, n=10)$ obtained at the detection limit showed that this amperometric method for measuring the HRP tracer was suitable for the determination of AFM1.

\subsection{Optimisation of flow-injection immunoassay for AFM1 determination}

\subsubsection{Tracer dilution}

The dilution of AFM1-HRP conjugate should be a compromise between the high dilution required to achieve a low detection limit for AFM1 and that needed to produce a sufficiently high signal. The working tracer dilution was defined as the tracer dilution resulting in a signal that was around 100 times the noise $(S / N>100)$ [23,24]. Different dilutions between $1 / 400$ and $1 / 50$ were tested and a dilution of $1 / 200$ was selected as working tracer concentration $[\text { AFM1-HRP }]_{\mathrm{w}}$ for the assay.

During the experiments to establish the best tracer concentration, a continuous increase in the baseline current was observed. This effect could be attributed to tracer that was non-specifically absorbed to the tubing. Leakage of the conjugate then gave rise to the continuously increasing background current. In order to avoid this effect, different concentrations of Tween 20, in the range $0.01-1 \%(\mathrm{v} / \mathrm{v})$, were added to the carrier solution to prevent the absorption. A stable baseline was achieved with a concentration of $0.03 \%$ (v/v) Tween 20. Under these improved conditions, a 1/200 dilution of tracer was shown to give a relative standard deviation of $1.65 \%$ for $n=12$.

\subsubsection{Incubation time}

In order to establish a suitable incubation time, the Protein G column was re-introduced into the FI-IA system. Solutions of $[\text { AFM1-HRP }]_{\mathrm{W}}$ were incubated with $1 \mathrm{ppm}$ Ab for different lengths of time and then injected into the flow system to determine the time needed for the off-line antigen-antibody reaction to reach equilibrium. Fig. 4 shows that maximal binding of labelled antigen was observed after $1 \mathrm{~h}$ and thus an incubation time of $1 \mathrm{~h}$ was used for further experiments.

\subsubsection{Flow rate}

The flow rate is a parameter that has a significant influence on the retention of antigen-antibody complex by the Protein $\mathrm{G}$ column. Fig. 5 shows the ratio obtained between the signal corresponding to the mixture $\left(\mathrm{Ag}^{*}+\mathrm{Ab}\right)$ and the signal obtained just for $\mathrm{Ag}^{*}$ introduced using the same flow rate $\left(S_{\mathrm{Ag} *+\mathrm{Ab}} / S_{\mathrm{Ag}^{*}}\right)$ for different overall flow rates. At low flow rates this ratio is relatively high due to the large dispersion of the sample during its transport from the injecting point to the detector. At a flow rate higher then $1.2 \mathrm{ml} \mathrm{min}^{-1}$ the contact

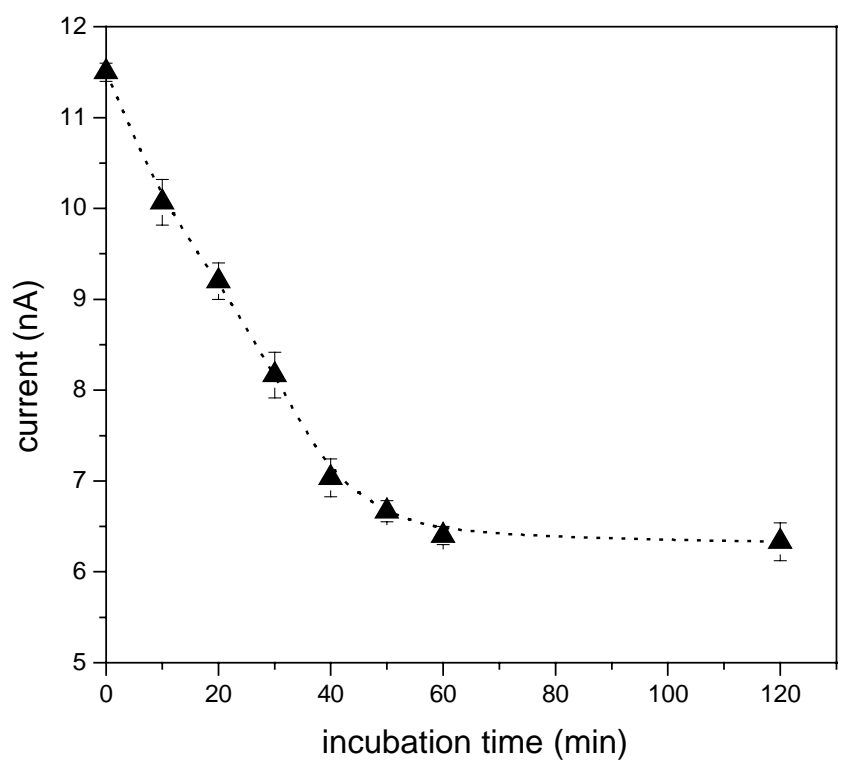

Fig. 4. The effect of the incubation time on the response for AFM1-HRP diluted 1/200 and incubated with $1 \mathrm{ppm} \mathrm{Ab}$ at room temperature (22 \pm $1{ }^{\circ} \mathrm{C}$ ). Working conditions: $10 \mathrm{mM} \mathrm{H}_{2} \mathrm{O}_{2} ; 0.5 \mathrm{mM} \mathrm{TMB}$; total flow rate $0.9 \mathrm{ml} \mathrm{min}^{-1}$.

time between the antigen-antibody complex and Protein $G$ is not sufficient and the ratio begins to increase. At the flow rate of $0.9 \mathrm{ml} \mathrm{min}^{-1}$ a minimum is obtained, which seems to reflect the optimal separation of Ab-bound tracer from free tracer, with good retention of the immuno complexes by the Protein G. This flow rate was selected for the assay.

\subsubsection{Antibody concentration}

For selection of the antibody concentration, an antibody dilution curve was performed and the results are shown in

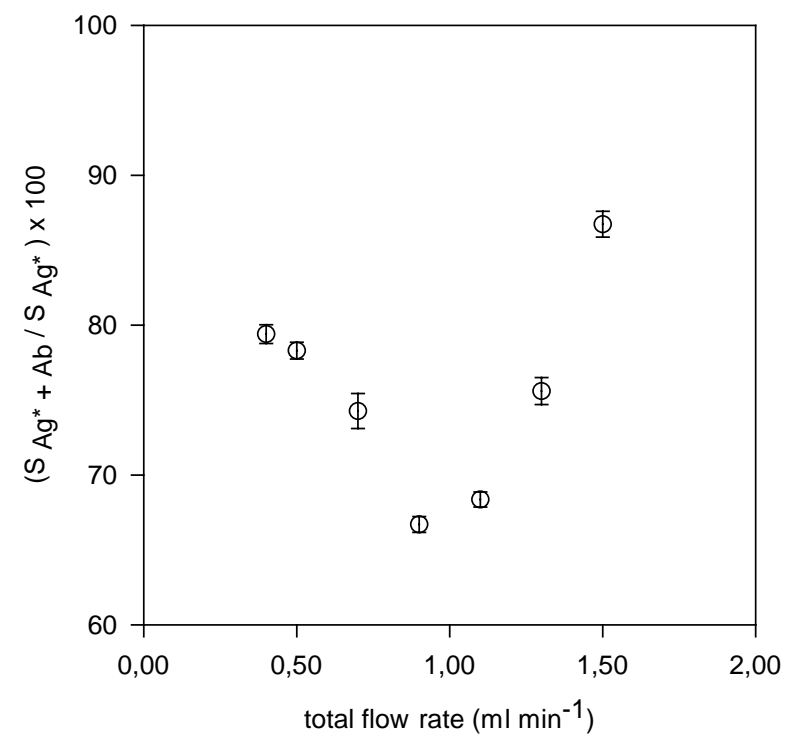

Fig. 5. The effect of the flow rate on trapping in the Protein G column of the antigen-antibody complex. Working conditions: AFM1-HRP diluted $1 / 200 ; 1$ ppm antibody; $60 \mathrm{~min}$ incubation; $10 \mathrm{mM} \mathrm{H}_{2} \mathrm{O}_{2} ; 0.5 \mathrm{mM}$ TMB. 


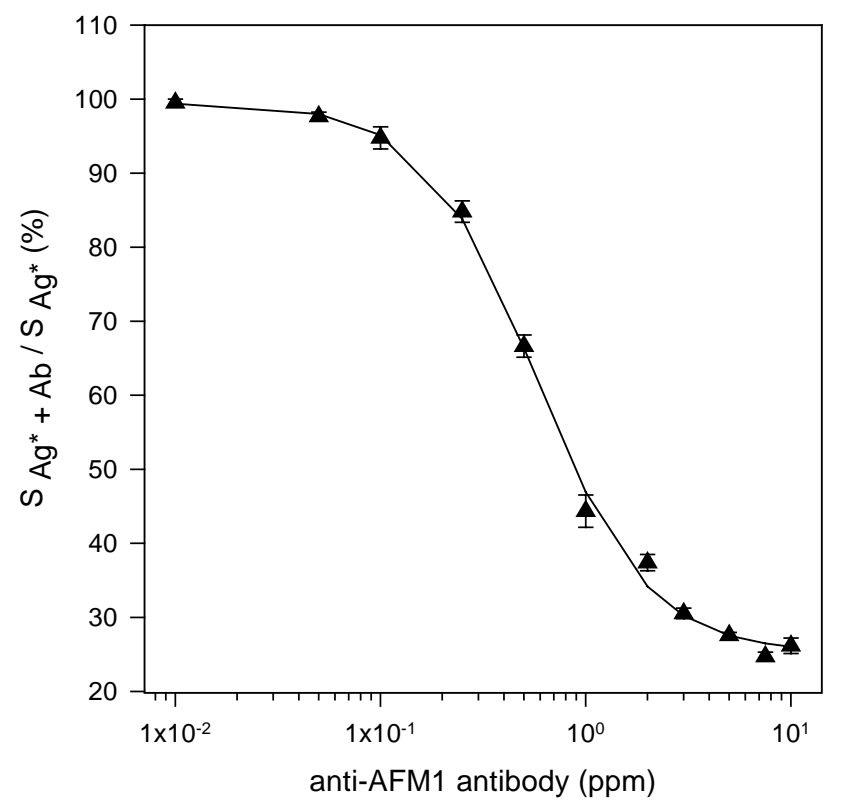

Fig. 6. Antibody dilution curve: the relative response $S_{\mathrm{Ag}^{*}+\mathrm{Ab}} / S_{\mathrm{Ag}^{*}} 100$ plotted vs. antibody concentration. $S_{\mathrm{Ag}^{*}}$ is the signal for the tracer fraction $\left(\mathrm{Ag}^{*}\right)$ without the antibody present in the system and $S_{\mathrm{Ag}^{*}+\mathrm{Ab}}$ is the signal for the free-eluting tracer when the antibody is present in the system. Working conditions: AFM1-HRP diluted 1/200; $60 \mathrm{~min}$ incubation; $10 \mathrm{mM}$ $\mathrm{H}_{2} \mathrm{O}_{2} ; 0.5 \mathrm{mM} \mathrm{TMB}$; total flow rate $0.9 \mathrm{ml} \mathrm{min}^{-1}$.

Fig. 6. A logistic equation with four parameters (fitted using a Jandel SigmaPlot 5.00 program) was used to analyse the data. The $\mathrm{Ab}$ concentration, which binds $50 \%$ of the tracer $\left(\mathrm{Ab}_{50}\right)$, was found to be $0.57 \mathrm{ppm}$. In a competitive immunoassay, the working antibody concentration $\left(A b_{w}\right)$ is normally chosen to correspond to a value giving 30-70\% tracer binding, depending on the desired assay properties [24]. In our case a value slightly higher than $\left(A_{50}\right)$ was chosen $(1 \mathrm{ppm})$, since better signals were obtained in this region of the curve.

\subsubsection{Characteristics of FI-IA assay}

To assess the performance of the system for the determination of AFM1, a calibration was done by incubating various concentrations of AFM1 with a 1/200 dilution of tracer and $1 \mathrm{ppm} \mathrm{Ab}$ for $60 \mathrm{~min}$ and injecting the samples into the FI-IA system. An increase in the signal (current) was observed with increasing AFM1 concentration. The data were fitted using a logistic equation with four parameters and the $\mathrm{IC}_{50}$ (analyte concentration at 50\% binding of the tracer) was calculated. The FI-IA immunoassay was then evaluated in terms of sensitivity, precision and selectivity (Table 1) on the basis of three different calibration curves obtained on three different days. The assay showed a good precision within the quantification range (20-500 ppt) and a satisfactory detection limit (11 ppt) relative to the requirements for the application of this for AFM1 determination in milk samples for regulatory purposes.

The cross-reactivity of this immunoassay format was studied using other mycotoxins such as AFB1, AFB2, AFG1
Table 1

The main parameters of the optimised FI-IA for AFM1 determination

\begin{tabular}{lccc}
\hline & Assay 1 & Assay 2 & Assay 3 \\
\hline Calibration points $(N)$ & 12 & 13 & 12 \\
Replicates & 3 & 3 & 3 \\
LOD $^{\mathrm{a}}$ (ppt) & $10.4 \pm 0.9$ & $11.1 \pm 0.9$ & $10.9 \pm 1.0$ \\
Dynamic range $^{\mathrm{b}}$ (ppt) & $20-500$ & $20-500$ & $20-500$ \\
$\mathrm{IC}_{50}$ (ppt) & $160.6 \pm 16.6$ & $165.8 \pm 22.1$ & $181.3 \pm 17.9$ \\
$\mathrm{RSD}^{\mathrm{c}}$ Intra-assay (\%) & 3.80 & 4.54 & 4.21 \\
$\mathrm{RSD}^{\mathrm{c}}$ Inter-assay (\%) & & 7.90 & \\
\hline
\end{tabular}

a The analyte concentration that gives a response equal with three times the standard deviation of the zero dose.

$\mathrm{b}$ The concentration range that led to a relative change in signal between 20 and $80 \%$, when compared with the zero dose.

c The mean RSD (\%) calculated only within the dynamic range of the response.

and ochratoxin. Calibrations for these cross-reactants were performed and for each cross reactant the corresponding $\mathrm{IC}_{50}$ was calculated. The relative cross-reactivity (CR) of the tested toxins is presented in Table 2 taking the $\mathrm{IC}_{50}$ value for AFM1 as reference. Cross-reactivities of $28.9 \%$ for AFB1 and $18.5 \%$ for AFB2 were obtained. As AFB1 and AFB2 are usually not found in the cow milk, this cross-reaction is not relevant when analysing aflatoxin M1 in this kind of sample $[25,26]$.

\subsection{Real sample analysis}

\subsubsection{Effect of matrix components on the immunoassay characteristics}

The effect of matrix components was evaluated by assay of a raw milk sample, for which a non-detectable AFM1 content was established by use of the HPLC method. Raw milk contained endogenous lactoperoxidase, which was shown to interfere strongly with the monitoring of the free fraction of tracer. Different methods for lactoperoxidase inactivation were tested and the best results were obtained with thermic inactivation, that is by heating the milk for $2 \mathrm{~min}$ at $90^{\circ} \mathrm{C}$. After cooling to room temperature, the milk sample was diluted 1:1 with double strength carrier buffer. Fig. 7 shows the AFM1 calibration plots obtained when AFM1 was added either to phosphate buffer or raw milk. Each point in the graph represents the mean of the values obtained for calibrations performed on three different days. As can be seen,

Table 2

Cross-reactivity of the optimised FI-IA

\begin{tabular}{lcc}
\hline Mycotoxin & IC $_{50}(\mathrm{ppt})$ & $\mathrm{CR}(\%)$ \\
\hline AFM1 & 169 & 100.0 \\
AFB1 & 584 & 28.9 \\
AFB2 & 910 & 18.5 \\
AFG1 & 16180 & 1.0 \\
Ochratoxin & N.d. & N.d. \\
\hline
\end{tabular}

N.d. means not detectable. 


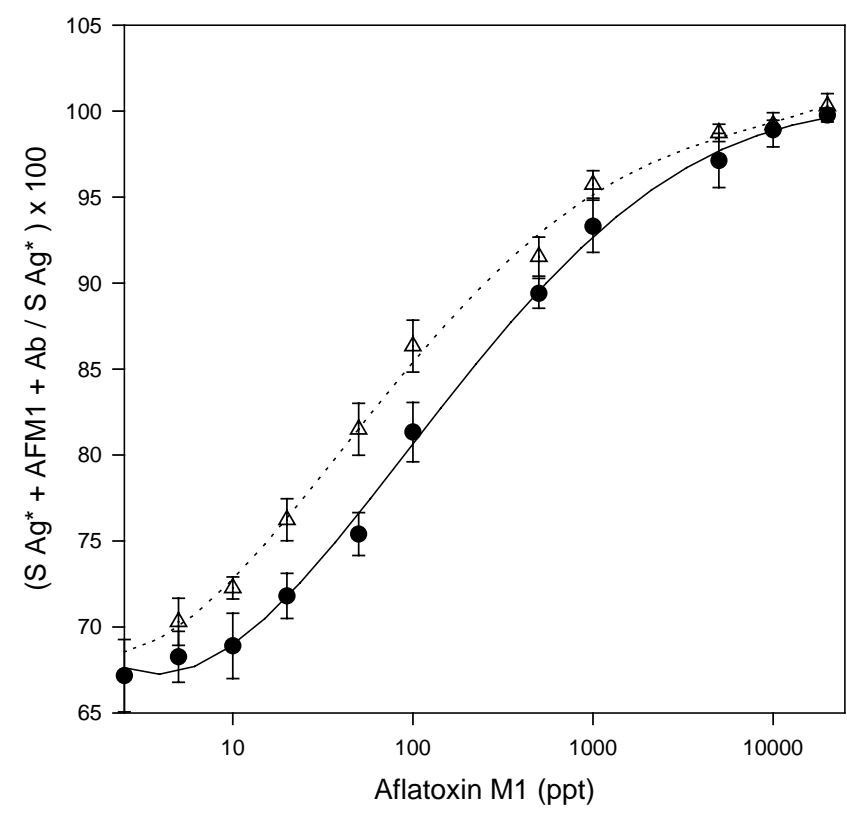

Fig. 7. AFM1 calibration curves for $(-)$ phosphate buffer and $(\rho)$ spiked raw milk diluted 1:1 with phosphate. Working conditions: AFM1-HRP diluted 1/200; $1 \mathrm{ppm}$ antibody; $60 \mathrm{~min}$ incubation; $10 \mathrm{mM} \mathrm{H}_{2} \mathrm{O}_{2} ; 0.5 \mathrm{mM}$

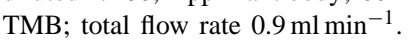

the behaviour and the sensitivity were similar in the two situations and good recoveries were obtained.

\subsubsection{Analysis of real samples and comparison with HPLC procedure}

To assess the accuracy of results obtained with the optimised FI-IA method, an HPLC procedure (AOAC 2000.08) was chosen for comparison. This standard procedure was improved by the introduction of a clean-up step (immunoaffinity column) in the sample treatment procedure.

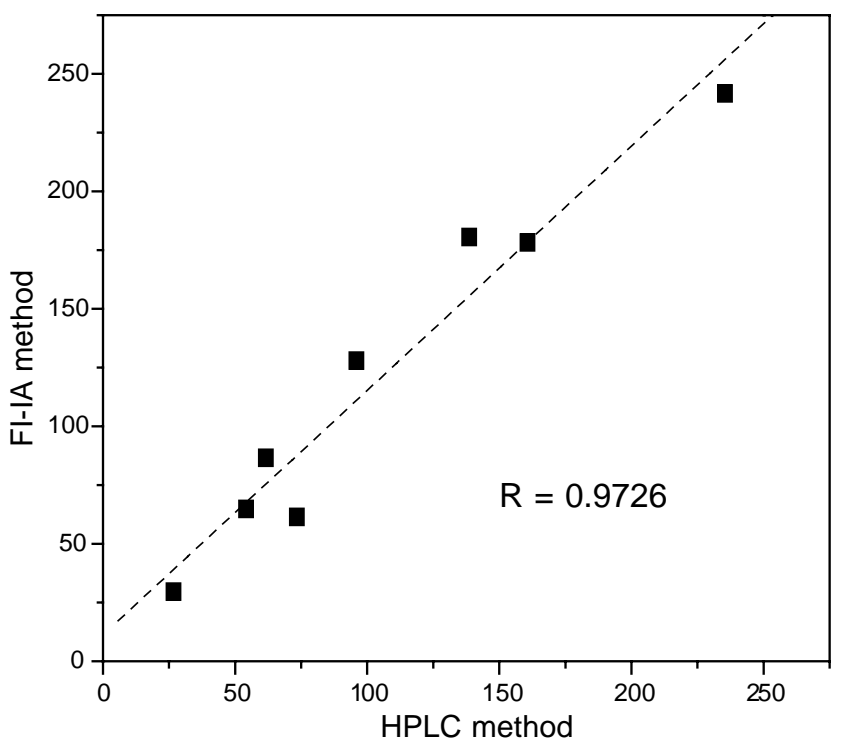

Fig. 8. Correlation between the proposed FI-IA and HPLC (AOAC 2000.08) methods for the aflatoxin M1 determination in milk samples.
Different UHT and raw milk samples, spiked or naturally contaminated, were analysed with both the procedures and the results, shown in Fig. 8, were in a satisfactory agreement $(R=0.9726)$.

\section{Conclusions}

The optimised flow-injection immunoassay for AFM1 has been shown to have a good potential as a method for rapid screening of this toxin in raw milk. The detection limit of $20 \mathrm{ppt}$ obtained for milk samples (taking into consideration the dilution 1:1 of the samples) allows the application of this method at dairy industry laboratories.

The sample preparation is very simple and fast (just heating and dilution) in comparison with the HPLC and ELISA procedures.

This assay resulted in a high throughput (six samples in triplicate per hour). The regeneration of the Protein $\mathrm{G}$ column (with $0.5 \mathrm{ml} 50 \%$ ) methanol is recommended after 50 injections to keep the column fresh.

This method offers strong advantages, such as good reproducibility $\left(\mathrm{RSD}_{\text {inter-assay }}<8 \%\right.$ ), selectivity (due to the use of a monoclonal antibody), good recoveries (80-120\%) and a low consumption of reagents. The results obtained with the FI-IA method are in good agreement with those obtained with the official HPLC procedure. The proposed flow-injection immunoassay system involves low cost instrumentation, is easy to operate and is very suitable to automation.

\section{Acknowledgements}

The authors gratefully acknowledge financial support from the EU (contract QLK1-CT-2001-01617). We would like to thank Dr. Nancy Downer for her valuable assistance during the preparation of the manuscript. Special acknowledgements are addressed to Professor Jenny Emnéus for the previous experience achieved by M.B. with her team, in Lund University, Sweden.

\section{References}

[1] D.L. Eaton, J.D. Groopman (Eds.), The Toxicology of Aflatoxins, Academic Press, New York, 1994, p. 521.

[2] H.P. Van Egmond, Introduction in Mycotoxins in Dairyproducts, Elsevier Applied Science, London, 1989, pp. 1-10.

[3] International Agency for Research on Cancer, IARC Monographs on the Evaluation of Carcinogenic Risk to Humans, vol. 56, World Health Organisation, Lyon, 1993.

[4] L. Stoloff, J. Food Prot. 43 (1989) 220.

[5] E.E. Creppy, Toxicol. Lett. 127 (2002) 19.

[6] European Commission, Commission Regulation 466/2001, Off. Eur. Comm. L77 (2001) p. 7.

[7] J. Stroka, E. Anklam, Trends Anal. Chem. 21 (2002) 90.

[8] J. Gilbert, E. Anklam, Trends Anal. Chem. 21 (2002) 468. 
[9] E. Papp, K.H. Otta, G. Zaray, E. Mincsovics, Microchem. J. 73 (2002) 39.

[10] P. Simon, P. Delsaut, M. Lafontaine, Y. Morele, T. Nicot, J. Chromatogr. B 712 (1998) 95.

[11] J. Stroka, E. Anklam, U. Joerissen, J. Gilbert, J. AOAC Int. 84 (2001) 116.

[12] A. Amine, L. Micheli, D. Moscone, G. Palleschi, in: G. Smit (Ed.), Dairy processing, CRC Press, Woodhead Pub., Cambridge, 2003, pp. 294-299.

[13] C.K. Holtzapple, R. J Carlin, B.G. Rose, L.F. Kubena, L.H. Stanker, Mole. Immunol. 33 (1996) 939.

[14] K. Thirumala-Devi, M.A. Mayo, A.J. Hall, P.Q. Craufurd, T.R. Wheeler, F. Waliyar, A. Subrahmanyam, D.V.R. Reddy, J. Agric. Food. Chem. 50 (2002) 933.

[15] C.E. López, L.L. Ramos, S.S. Ramadán, L.C. Bulacio, Food Control 14 (2003) 31.

[16] M.A. Carlson, C.B. Bargeron, R.C. Benson, A.B. Fraser, T.E. Phillips, J.T. Velky, J.D. Groopman, P.T. Strickland, H.W. Ko, Biosens. Biolectronics 14 (2000) 841.

[17] L. Sibanda, S. De Saeger, C. Van Peteghem, Int. J. Food Microbiol. 48 (1999) 203.
[18] V.G. Andreou, D.P. Nikolelis, Anal. Chem. 70 (1998) 2366.

[19] E. Burestedt, C. Nistor, U. Schagerlöf, J. Emnéus, Anal. Chem. 72 (2000) 4171.

[20] B. Bjarnason, L. Chimuka, P. Önnerfjord, S. Eremin, J.-Å. Jönsson, G. Johansson, J. Emnéus, Anal. Chim. Acta 426 (2001) 197.

[21] M. Badea, C. Nistor, S. Goda, S. Fujimoto, S. Dosho, D. Danet, D. Barceló, F. Ventura, J. Emnéus, Analyst 128 (2003) 849.

[22] G. Volpe, D. Compagnone, R. Draisci, G. Palleschi, Analyst 123 (1998) 1303.

[23] C. Nistor, A. Oubiña, M.P. Marco, D. Barceló, J. Emnéus, Anal. Chim. Acta 426 (2001) 185.

[24] L. Brian (Ed.), Immunoassay-A Practical Guide, Taylor \& Francis, London, 1996.

[25] L.A. Goldblatt, in: P. Krogh (Ed.), Symposium on the Control of Mycotoxins, 21-22 August 1972, International Union of Pure and Applied Chemistry, Applied Chemistry Division (IUPAC), Butterworths Press, London, 1972, p. 223.

[26] I.F.H. Purchase, in: P. Krogh (Ed.), Symposium on the Control of Mycotoxins, 21-22 August 1972, International Union of Pure and Applied Chemistry, Applied Chemistry Division (IUPAC), Butterworths Press, London, 1972, p. 283. 